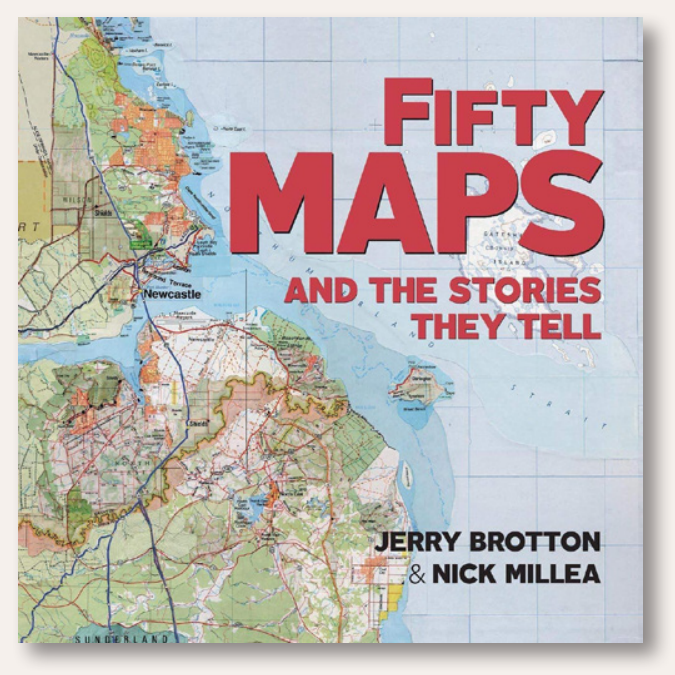

\section{FIFTY MAPS AND THE STORIES THEY TELL}

By Jerry Brotton and Nick Millea

Bodleian Library/University of Oxford, 2019

144 pages, 80 color plates

Softcover: \$20.00, ISBN 978-1-85124-523-9

Review by: Jörn Seemann, Ball State University
ThE INTEREST IN OLD MAPS and the history of cartography seems to be increasing, and this trend is reflected in the book market. A large number of volumes on historical maps, the history of cartography, and the life and work of specific mapmakers have been published in recent years, and the up-tick shows no sign of slowing. Interested readers can choose from books with such catchy titles as Theater of the World: The Maps That Made History (Berg 2018), Maps: Their Untold Stories (Mitchell and Janes 2014) or Maps: Finding Our Place in the World (Akerman and Karrow 2007). Some titles promote the quantity of their contents, along the lines of trendy clickbait articles advertising "[some number] of [places or things] to [somehow experience] before you die"-among them one finds: $A$ History of the Twentieth Century in 100 Maps (Bryars and Harper 2014), A History of America in 100 Maps (Schulten 2018) or 100 Maps That Changed the World (Harwood 2012). Some famous map libraries have also jumped on this cartographic bandwagon and released their own picture books, where they highlight the most celebrated and/or curious pieces in their collections (Barber and Board 1993; Rumsey and Punt 2004; Virga 2007; Hall 2016; Harper 2019). This very journal, Cartographic Perspectives, regularly publishes reviews of this type of book. How does Fifty Maps and the Stories They Tell fit into this publishing trend? Is it just another map book, or does it present a different approach to map history? It certainly promises a lot, and shows a good leg, but it is no exhaustive coffee table volume.

The editors of this compilation are well-known history of cartography scholars. Nick Millea has been the map librarian at the Bodleian Library at the University of Oxford since 1992. He is a contributor to the journal Imago Mundi and has been organizing the renowned and ongoing Oxford Seminars in Cartography lecture series. Jerry Brotton is a Professor of Renaissance Studies at Queen Mary University of London, a television and radio host (notably, of the British Broadcasting Corporation series Maps: Power, Plunder, and Possession) and a curator of exhibitions. He has written an insightful book on the mapping of the early modern world (Trading Territories: Mapping the Early Modern World, 1997), edited a popular coffee table book with the title Great Maps: The World's Masterpieces Explored and Explained (2014), and is the author of the bestselling A History of the World in Twelve Maps (2012).

Fifty Maps and the Stories They Tell comes as a seven-byseven-inch softcover, and presents 50 maps from the Bodleian Library that are arranged in chronological order. With a few exceptions, each entry is given a two-page spread containing an image of the complete map, with a caption and one paragraph of text to place the map in its historical context and to describe its contents. Some maps, such as Al-Idrisi's twelfth-century Nuzhat al-mushtaq ("Entertainment for he who longs to travel the world"), the Gough map of Great Britain (c. 1390-1410), a Tudor tapestry map (c. 1590), and Selden's early seventeenth-century ink-on-paper map of China by an anonymous Chinese mapmaker, get two-paragraph discussions with zoomedin image details laid out over four pages.

The selection of maps includes cartographic "staples" such as the fifteenth-century print of Claudius Ptolemy's 
world map, European and Arabic medieval mappae mundi, early maps of Dante Alighieri's Hell and Thomas More's Utopia, an Aztec map of Tenochtitlan from the Codex Mendoza (1542), a Marshall Islands stick chart, and handdrawn sketches for both J. R. R. Tolkien's Middle-Earth and C. S. Lewis's Narnia. The authors admit it was not a simple matter to select just fifty maps from the Bodleian's impressive collection of more than 1.5 million, and they are eager to point out the diversity and pluralism to be found in cartography by selecting maps from different times, backgrounds, and places that showcase a variety of different narratives, purposes, themes, and worldviews. I was pleased to find that the book was not an account of exclusively Western cartographic history, and included maps and mappings from other cultures. Western, or European, cartography has long focused on the precision of measurements, coordinates, and location, but of these fifty maps, almost one quarter are non-European cartographic renderings of topics and values such as cosmology, mythology, and indigenous conceptions of space that-in conventional "Western" terms-would be considered immeasurable or even "unmappable." For example, a page from an eighteenth/nineteenth-century copy of The Tibetan Book of the Dead does not resemble a conventional Western map at all, but is "a spiritual route map to salvation" that serves as a "funerary manual shown to the dying to help the soul navigate through the liminal world ... between death and rebirth" (81). The sealskin map appearing on page 86, made by a member of the Chukchi people in Siberia (c. 1860), with its depiction of hunting grounds, fishing areas, and fur trade routes close to the Bering Strait, can be read as both a calendar of economic activities throughout the year and a narrative of daily life and customs. These examples definitely broaden the idea of maps beyond traditional Western ideas.

Another positive surprise is the inclusion of unconventional maps from the twentieth and twenty-first centuries. Of course, there are thematic "regulars" that appear in almost every book on the history of cartography: a map of the British Empire (here, it is Philip's Mercantile Chart of the Commercial Routes to the East, 1906), a trench map of the Belgian front during World War I (1917), a D-Day landing map, and a shockingly accurate topographic map sheet of English towns produced by the Soviet military during the Cold War. But, beyond these, the reader can also find curiosities that are likely unavailable outside the Bodleian Library, and might not even be found on the internet. The map of the working-class neighborhood of Cutteslowe in Oxford (1933) includes handwritten notes and corrections, including walking times to bus stops, and the addition of two massive brick "protection walls" that separated a low-income housing project from an affluent urban development-cartographic testimony to an "urban apartheid in Oxford" (104-105). Other unusual selections include sketch maps handed out to soldiers participating in the 1951 British military operation "Exercise Surprise Packet" that showed an imaginary United Kingdom where Scotland and the northern part of England are labeled as Fantasia and connected with Scandinavia by a land bridge (122-123).

No one said that "historical" maps must be "old," or even on paper, so Brotton and Millea do not exclude examples from the most recent chapters in cartographic history. A cartogram of the 2017 British general election (134-135) and a wildly distorted grid map of the world population (138-139) point out new directions in cartography.

In addition to these cartographic surprises, the editors also include three artistic works that establish a link between maps, society, and the arts. Layla Curtis's NewcastleGateshead (2005) is a map collage that merges the Tyne and Wear region in Northeast England with cutout pieces from maps of other places (128-129). A light green area northwest from Newcastle features parts of the Australian desert near Alice Springs, and the name of Newcastle appears fifty-two times on the map. Grayson Perry's Map of Nowhere (2008) simultaneously imitates the Ebstorf mappa mundi with its body-of-Christ shape and mocks both medieval theological worldviews and present-day self-centeredness (130-131). Another Perry work, The Red Carpet (2017), is a tapestry map in the style of an Afghan war rug-a traditional motif in Afghan rug-making dating back to 1979 that incorporates military and battle imagery, and often includes maps-with embroidered buzzwords portraying the zeitgeist of the pre-Brexit society in Great Britain (136-137).

Although Fifty Maps and the Stories They Tell is a nice read-and a quick one - that introduces a general audience to the fascinating world of historical maps, it remains rather superficial. The authors present ideas and clues on maps and mapmaking, but they do not explore them at all deeply. I was expecting more on the story-telling potential of maps or on the specific uses and purposes of maps in different societies, but, unfortunately, the authors missed their opportunity. Without a more comprehensive explanation, statements in the Introduction like, "Every map tells a story, and Fifty Maps is a celebration of the 
sheer variety of those stories, told by travellers, sailors, merchants, pilgrims and many others" (7) come across as shallow and oversimple, and fail to reflect the complexity, density, and diversity of mapping the world.

Fifty Maps was assembled to accompany the Bodleian Library's Talking Maps Exhibition (July 2019-March 2020), a show that also resulted in a far more detailed and weightier catalog, Talking Maps (Brotton and Millea 2019). As well, in keeping with the publication trends mentioned at the beginning of this review, the Bodleian Library has recently brought out another book showcasing their extensive collections, Treasures from the Map Room (Hall 2016; reviewed in Cartographic Perspectives 89). As a result, there are many repetitions and overlaps between Fifty Maps, Talking Maps, and Treasures. All in all, Fifty Maps and the Stories They Tell comes out as an ultralight variant of the new crop of Bodleian books. The text is informative, but really only scratches the surface of map history. I expect that most $C P$ readers would like to know more about the topics and maps it touches on so lightly. The general "further reading" bibliography at the end of the book can only partially make up for this shortcoming.

So is this just another map book? Maybe. It is definitely targeted at those who really only want a quick sampler or are not yet ready for a bulkier tome on the history of cartography. If, as seems to be the case, the Bodleian Library intends to provide a map collection product for every level of interest, expertise, and pocketbook, they should seriously consider offering a map postcard book like Antique Maps from the Library of Congress (1999), as well as upgrading their singularly disappointing website (bodleian. ox.ac.uk/maps). At any rate, Fifty Maps is an entry-level, budget book that piques the reader's curiosity to explore other works on the topic. Needless to say, there is much to discover.

\section{REFERENCES}

Akerman, James, and Robert Karrow, eds. 2007. Maps: Finding Our Place in the World. Chicago: University of Chicago Press.

Barber, Peter, and Christopher Board. 1993. Tales from the Map Room. Fact and Fiction about Maps and Their Makers. London: BBC Books.
Berg, Thomas Reinertsen. 2018. Theater of the World: The Maps that Made History. New York, Boston, London: Little, Brown and Company.

Brotton, Jerry. 1997. Trading Territories: Mapping the Early Modern World. London: Reaktion Books. 2012. A History of the World in Twelve Maps. New York: Viking.

. 2014. Great Maps: The World's Masterpieces Explored and Explained. London: Dorling Kindersley.

Brotton, Jerry, and Nick Millea. 2019. Talking Maps. Oxford: Bodleian Library/University of Oxford.

Bryars, Tim, and Tom Harper. 2014. A History of the Twentieth Century in 100 Maps. Chicago: University of Chicago Press.

Hall, Debbie. 2016. Treasures from the Map Room. A Journey through the Bodleian Collections. Oxford: Bodleian Libraries.

Harper, Tom. 2019. Atlas: A World of Maps from the British Library. London: British Library Publishing.

Harwood, Jeremy. 2012. To the Ends of the Earth: 100 Maps That Changed the World. New York: Chartwell Books.

Library of Congress. 1999. Antique Maps: Library of Congress. Rohnert Park, CA: Pomegranate.

Mitchell, Rose, and Andrew Janes. 2014. Maps: Their Untold Stories. Map Treasures from the National Archives. London: Bloomsbury Publishing.

Rumsey, David, and Edith Punt. 2004. Cartographica Extraordinaire: The Historical Map Transformed. Redlands, CA: ESRI Press.

Sauer, Carl O. 1956. "The Education of a Geographer." Annals of the Association of American Geographers 46 (3): 287-299. https://doi.org/10.1111/j.1467-8306.1956. tb01510.x.

Schulten, Susan. 2018. A History of America in 100 Maps. Chicago: University of Chicago Press.

Virga, Vincent. 2007. Cartographica: Mapping Givilizations. New York, Boston, London: Little, Brown and Company. 